\title{
Synthesis and properties of phosphonic acid-grafted hybrid inorganic-organic polymer membranes
}

\author{
Siwen Li, ${ }^{a}$ Zhen Zhou, ${ }^{a}$ Harry Abernathy, ${ }^{a}$ Meilin Liu, ${ }^{* a}$ Wen Li, ${ }^{b}$ Junzo Ukai, ${ }^{b}$ Kohei Hase ${ }^{c}$ and \\ Masatsugu Nakanishi ${ }^{c}$
}

Received 1st September 2005, Accepted 7th December 2005

First published as an Advance Article on the web 19th December 2005

DOI: $10.1039 / \mathrm{b512389e}$

A class of phosphonic acid-grafted hybrid inorganic-organic polymer membranes was synthesized using a sol-gel process. Their thermal stability, water uptake, and proton conductivity were investigated. TGA-DSC analysis indicated that these membranes are thermally stable up to at least $220{ }^{\circ} \mathrm{C}$ in dry air. The proton conductivities of the new membranes increase with $-\mathrm{PO}_{3} \mathrm{H}_{2}$ group content and relative humidity, reaching $6.2 \times 10^{-2} \mathrm{~S} \mathrm{~cm}^{-1}$ at $100{ }^{\circ} \mathrm{C}$ with $\sim 100 \%$ relative humidity, comparable to those of Nafion ${ }^{\mathbb{R}}$ under similar conditions. These new membranes have high proton conductivity at low relative humidity and thus have great potential to be used as electrolytes for high-temperature, low-humidity PEM fuel cells and other electrochemical applications. The proton conductivity of the membranes in the anhydrous state was enhanced by substitution of $-\mathrm{CH}_{2}-\mathrm{PO}_{3} \mathrm{H}_{2}$ groups with $-\mathrm{CF}_{2}-\mathrm{PO}_{3} \mathrm{H}_{2}$ groups owing to the large electronwithdrawing effect of $\mathrm{C}-\mathrm{F}$ bonds. However, it was found that the concentration of $-\mathrm{PO}_{3} \mathrm{H}_{2}$ groups and the molecular structures of the new membranes are the key factors for the proton transport process in a humidified environment.

\section{Introduction}

Proton exchange membranes (PEMs) are a critical component in fuel cells, hydrogen separation/purification, reforming/partial oxidation of hydrocarbon fuels, contaminant removal, gas sensing, and other processes relevant to energy storage and conversion. While various electrolyte membranes have been studied for many years, the existing membranes are still inadequate in performance for the intended applications. The widely used perfluorosulfonic polymers (mainly Nafion ${ }^{\circledR}$ ) have relatively low proton conductivity over $100{ }^{\circ} \mathrm{C}$, large amount of gas crossover, significant dimensional changes with water content, high cost, and the decomposition of $-\mathrm{SO}_{3} \mathrm{H}$ groups under fuel cell working conditions. ${ }^{1-7}$ These limitations have stimulated intense interest in the development of new proton conducting membranes, including polymer proton electrolytes with nanometer-sized hygroscopic metal oxides, ${ }^{8,9}$ sulfonated aromatic polymer membranes, polymer- $\mathrm{H}_{3} \mathrm{PO}_{4}$ membranes, ${ }^{10-12}$ and hybrid inorganic-organic proton conducting membranes doped with proton-conductive components, including $\mathrm{H}_{3} \mathrm{PO}_{4}$, heteropolyacids, and grafted $-\mathrm{SO}_{3} \mathrm{H}$ groups. ${ }^{12-16}$

Hybrid inorganic-organic polymers have been extensively studied as PEMs in which inorganic networks are crosslinked through organic chains on a molecular scale. Protonconductive compounds $\mathrm{Zr}\left(\mathrm{HPO}_{4}\right)_{2} \cdot \mathrm{H}_{2} \mathrm{O}$, silicotungstic acid,

${ }^{a}$ Center for Innovative Fuel Cell and Battery Technologies, School of Materials Science and Engineering, Georgia Institute of Technology, Atlanta, GA,30332-0245,USA.E-mail:meilin.liu@mse.gatech.edu; Fax: +1-404-894-9140; Tel: +1-404-894-6114

${ }^{b}$ Materials Engineering Department, Toyota Technical Center, USA, Inc., Ann Arbor, MI 48105, USA

${ }^{c}$ Material Engineering Division II, Vehicle Engineering Group, Toyota Motor Corporation, Toyota, Aichi 471-8572, Japan and 12-phosphotungstic acid have been introduced into hybrid polymers. ${ }^{3,13-15}$ In these membranes, large amounts of inorganic compounds are necessary for high proton conductivity, thus limiting the mechanical properties of the membranes. Sulfonic acid group-grafted hybrid inorganicorganic copolymer membranes displayed high proton conductivities under conditions of high relative humidity below $100{ }^{\circ} \mathrm{C}$, similar to Nafion ${ }^{\circledR}$ membranes. ${ }^{1,16}$ However, they have very limited thermal stability because of the strong acidity and the oxidizing effect of sulfonic acid groups. ${ }^{16}$

Here we report a series of new proton conducting membranes based on hybrid inorganic-organic polymers with grafted $-\mathrm{PO}_{3} \mathrm{H}_{2}$ groups or $-\mathrm{CF}_{2}-\mathrm{PO}_{3} \mathrm{H}_{2}$ groups. $-\mathrm{PO}_{3} \mathrm{H}_{2}$ groups are stable in reducing environments and have higher water holding ability than $-\mathrm{SO}_{3} \mathrm{H}$ groups. ${ }^{12}$ The new membranes were synthesized through a simple sol-gel process. Membranes of thickness less than $0.1 \mathrm{~mm}$ can be readily cast. Compared to Nafion ${ }^{\mathbb{B}}$ membranes, the new hybrid inorganicorganic membranes have comparable proton conductivities but with much less dependence on humidification.

\section{Experimental}

\subsection{Synthesis of precursors}

Phosphonic acid groups were grafted onto the hybrid inorganic-organic copolymer networks through a short organic chain via $\mathrm{Si-C}$ bonds. The precursors used in this study are diethyl-4-(diethoxy(methyl)silyl)-1,1-difluorobutylphosphonate (FP, see Scheme 1) and diethoxyphosphorylethyltriethoxysilane (CP, Gelest, 95\%, see Scheme 2). FP was synthesized according to Scheme 1, where compound (2) was synthesized as described elsewhere. ${ }^{17}$ In a typical experiment, 
<smiles>CCOP(=O)(OCC)C(F)(F)Br</smiles>

(1)<smiles>C=CCC(F)(F)P(=O)(OCC)OCC</smiles>

(2)<smiles>CCO[Si](C)(C)OCC</smiles><smiles>CCO[Si](C)(CCCC(F)(F)P(=O)(OCC)OCC)OCCO</smiles>

FP-h

FP

Scheme 1 Synthesis process of FP and its hydrolyzed form FP-h.

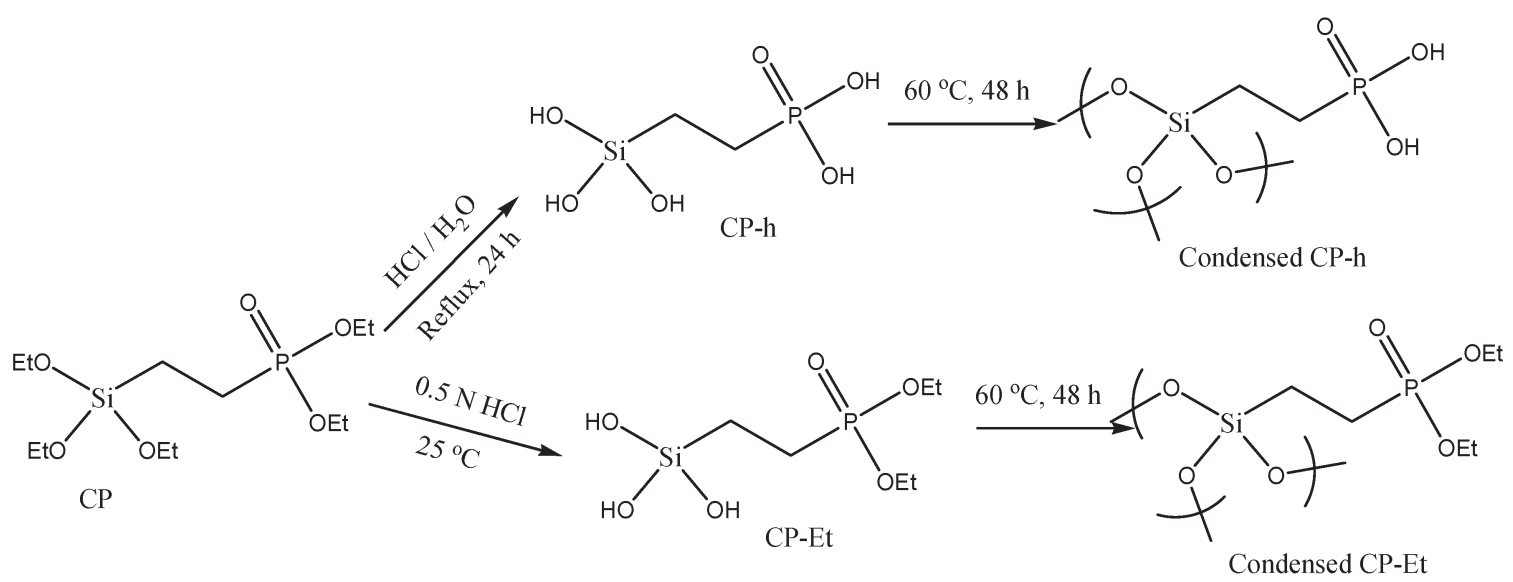

Scheme 2 Hydrolysis of CP to CP-h and CP-Et, and corresponding condensed forms.

$4.8 \mathrm{~g}(23.4 \mathrm{mmol})$ of compound (2) was mixed with $7.5 \mathrm{~g}$ (56 mmol) diethoxymethylsilane (3) and several drops of hydrogen hexachloroplatinate (4) solution (5\% in isopropanol). After stirring at $60{ }^{\circ} \mathrm{C}$ overnight, the solution was evaporated under reduced pressure to remove the reactants and product FP was obtained $(6.0 \mathrm{~g}, 16.6 \mathrm{mmol}$, yield $71 \%)$. ${ }^{1} \mathrm{H}$ NMR $\left(\mathrm{CDCl}_{3}\right): \delta(\mathrm{ppm}) 0.12(3 \mathrm{H}, \mathrm{s}), 0.65(2 \mathrm{H}, \mathrm{m})$, $1.21\left(6 \mathrm{H}, \mathrm{t}, J_{\mathrm{H}-\mathrm{H}}=6.98\right), 1.35\left(6 \mathrm{H}, 6, J_{\mathrm{H}-\mathrm{H}}=7.06\right), 1.65$ $(2 \mathrm{H}, \mathrm{m}), 2.15(2 \mathrm{H}, \mathrm{m}), 3.75\left(4 \mathrm{H}, \mathrm{q}, J_{\mathrm{H}-\mathrm{H}}=6.98\right), 4.26(4 \mathrm{H}, \mathrm{q}$, $\left.J_{\mathrm{H}-\mathrm{H}}=7.06\right)$.

\subsection{Hydrolysis of diethoxyphosphoryl groups}

The precursors FP and CP were hydrolyzed before use to change diethoxyphosphoryl groups to phosphonic acid groups in condensed hydrochloric acid as shown in Schemes 1 and 2. ${ }^{18}$ The process can be described with $\mathrm{CP}$ as an example: $3.28 \mathrm{~g} \mathrm{CP}$ $(\sim 10 \mathrm{mmol})$ was dissolved in $50 \mathrm{ml}$ of condensed hydrochloric acid aqueous solution by stirring in a three-necked flask with a condenser and an argon (Ar) gas line. The flask (under the protection of Ar) was immersed in an oil bath and kept at $90{ }^{\circ} \mathrm{C}$ for about 24 hours. After cooling down to $50{ }^{\circ} \mathrm{C}$, the hydrochloric acid aqueous solution was evaporated under reduced pressure, and transparent viscous solid dihydroxyphosphorylethyltrihydroxysilane (CP-h) was obtained with a yield of $100 \%$. The hydrolyzed form of FP, labeled as FP-h, is insoluble in condensed hydrochloric acid aqueous solution and water, but soluble in ethanol and methanol.

When $\mathrm{CP}$ was hydrolyzed in ethanol catalyzed with $0.5 \mathrm{~N}$ $\mathrm{HCl}$ aqueous solution, only $-\mathrm{Si}\left(\mathrm{OC}_{2} \mathrm{H}_{5}\right)_{3}$ will be changed to $-\mathrm{Si}(\mathrm{OH})_{3}$, while the $-\mathrm{PO}\left(\mathrm{OC}_{2} \mathrm{H}_{5}\right)_{2}$ groups will remain stable in this process (see Scheme 2). This partially hydrolyzed form was labeled as CP-Et. Condensed CP-Et and condensed CP-h were obtained by heating in air at $60{ }^{\circ} \mathrm{C}$ for several days.

\subsection{Preparation of membranes}

CP-h or FP-h were dissolved in ethanol together with bis[(3-methyldimethyoxysilyl)propyl]polypropylene oxide (M, Gelest, 96\%; MW 600-900, see Scheme 3), 1,4-bis(trimethoxysilylethyl)benzene (Be, Gelest, 98\%, see Scheme 3), bis(triethoxysilyl)octane (Oc, Gelest, 98\%, see Scheme 3), tetraethoxysilane (T), and/or (3-glycidoxypropyl)triethoxysilane (G, Scheme 3) (Alfa, 96\%). After stirring for 20 minutes, $0.5 \mathrm{~N} \mathrm{HCl}$ aqueous solution was added dropwise to the precursor solution, and further stirred for 12 to 48 hours. The 
<smiles>COC(C)CC(C)OCCC[Si](C)(OC)OC</smiles>

M<smiles>CO[Si](CCc1ccc(CC[Si](OC)(OC)OC)cc1)(OC)OC</smiles>

$\mathrm{Be}$<smiles>CCO[Si](CCCCCCCCC[Si](OCC)(OCC)OCC)(OCC)OCC</smiles>

Oc<smiles>CCO[Si](CCCOCC1CO1)(OCC)OCC</smiles>

G

Scheme 3 Molecule structures of precursors as network formers.

sols were cast on petri dishes. The amount of water added is 4 times of the total amount of $\mathrm{Si}$ in mol. The membranes were dried at $60{ }^{\circ} \mathrm{C}$ for 3 days, at $80{ }^{\circ} \mathrm{C}$ for 3 hours, and then at $100{ }^{\circ} \mathrm{C}$ for 1 hour to evaporate the organic solvents and water. The samples were labeled by their mole composition as $x \mathrm{M}-y \mathrm{Be}$ (or $\mathrm{Oc}$ ) $-z \mathrm{CP}$ (or $\mathrm{FP}$ ), where $x, y$, and $z$ represent the number of moles of $\mathrm{Si}$ from $\mathrm{M}, \mathrm{Be}$ (or Oc), and $\mathrm{CP}-\mathrm{h}$ (or FP-h), respectively. Typical values for $x$ are 1-2, y 2-4, and $z$ 3-6. The samples with $\mathrm{G}$ were labeled as $x \mathrm{G}-y \mathrm{~T}-z \mathrm{CP}$, where $x$, $y$, and $z$ represent the number of moles of $\mathrm{Si}$ from $\mathrm{G}, \mathrm{T}$, and CP-h, respectively. The typical values of $x, y$, and $z$ were $0-2$, $0-2$, and 2 , respectively.

\subsection{Characterization of membranes}

X-Ray diffraction patterns of the membranes were obtained using a Philips PW 1800 diffractometer with $\mathrm{Cu} \mathrm{K}_{\alpha}$ radiation. Fourier transform infrared (FTIR) spectroscopy measurements were performed on thin pellets composed of 5\% sample and $95 \% \mathrm{KBr}$ using a Bruker Equinox 55 spectrometer. Each spectrum presented is the sum of 64 scans at $4 \mathrm{~cm}^{-1}$ resolution. Thermogravimetric analysis (TGA) and differential scanning calorimetry (DSC) were performed in a Pt crucible with about $20 \mathrm{mg}$ of samples using a Rheometric Scientific STA 1500 in dry air from room temperature to $500{ }^{\circ} \mathrm{C}$. ${ }^{1} \mathrm{H}$ NMR spectra was recorded with a Varian Mercury Vx 300 spectrometer operating at $300 \mathrm{MHz}$. Solid state ${ }^{31} \mathrm{P}$ MAS-NMR spectra were acquired using a Bruker DSX 400 spectrometer operating at $161.86 \mathrm{MHz}$. The ${ }^{31} \mathrm{P}$ signal from $\mathrm{NH}_{4} \mathrm{H}_{2} \mathrm{PO}_{4}$ at $298 \mathrm{~K}$ was referenced to $\delta=0 \mathrm{ppm}$. Small pieces of membranes were used to measure the proton conductivity using a SI 1255 frequency response analyzer and SI 1286 potentiostat/galvanostat in the frequency range of $0.01 \mathrm{~Hz}$ to $5 \mathrm{MHz}$. Two gold-coated silver pellets were used as the electrodes. The samples were kept at each temperature for 4-8 hours until the electrical responses of the samples became stable. Relative humidity $(\mathrm{RH})$ of $100 \%$ was maintained by excess water whereas RHs of $20 \%$ and $75 \%$ were supplied by a saturated aqueous solution of $\mathrm{MgCl}_{2}$ and $\mathrm{KCl}$, respectively, in a closed chamber. ${ }^{19}$

\section{Results and discussion}

\subsection{Formation of hybrid inorganic-organic polymers}

Shown in Fig. 1 are the FTIR spectra of condensed CP-h, condensed CP-Et, a membrane with a composition of $2 \mathrm{M}$ $4 \mathrm{Be}-4 \mathrm{CP}$, and a membrane with a composition of $2 \mathrm{M}-2 \mathrm{Be}-$ 6CP. The FTIR spectrum of condensed CP-Et has a strong peak at $2980 \mathrm{~cm}^{-1}$, corresponding to the $-\mathrm{CH}_{3}$ group in $-\mathrm{PO}\left(\mathrm{OC}_{2} \mathrm{H}_{5}\right)_{2}$. This peak disappeared from the spectrum of condensed CP-h, but a broad peak corresponding to $-\mathrm{P}-\mathrm{O}-\mathrm{H}$ groups appeared at $2320 \mathrm{~cm}^{-1}$, indicating that the $-\mathrm{PO}\left(\mathrm{OC}_{2} \mathrm{H}_{5}\right)_{2}$ group was hydrolyzed and changed to $-\mathrm{PO}_{3} \mathrm{H}_{2} \cdot{ }^{20}$ The strong peak of $\mathrm{Si}-\mathrm{O}-\mathrm{Si}$ asymmetric stretching vibration was observed at $1030 \mathrm{~cm}^{-1}$ in the spectra of condensed CP-h and CP-Et, and at $1100 \mathrm{~cm}^{-1}$ in those of the membranes with compositions of $2 \mathrm{M}-4 \mathrm{Be}-4 \mathrm{CP}$ and $2 \mathrm{M}-2 \mathrm{Be}-6 \mathrm{CP} .{ }^{21}$ This indicates that the inorganic backbone $-\mathrm{Si}-\mathrm{O}-\mathrm{Si}-\mathrm{O}-$ was formed in the drying process. X-Ray analysis of the membranes indicated that the as-prepared membranes were nearly amorphous. There was only one weak broad peak near $2 \theta=22^{\circ}$ in the XRD spectra (see Fig. 2), which may be assigned to the typical coherent diffraction domains of $\mathrm{Si}-\mathrm{O}$ based backbones of the hybrid inorganicorganic polymers. ${ }^{22,23}$ The XRD results further confirmed the formation of $\mathrm{Si}-\mathrm{O}-\mathrm{Si}$ based hybrid inorganic-organic polymer networks in the new membranes.

All as-prepared membranes were transparent, self-standing, and flexible (see Fig. 3). Self-standing membranes with a thickness of less than $100 \mu \mathrm{m}$ can be cast readily to large sizes depending on the molds. It should be mentioned that the sols

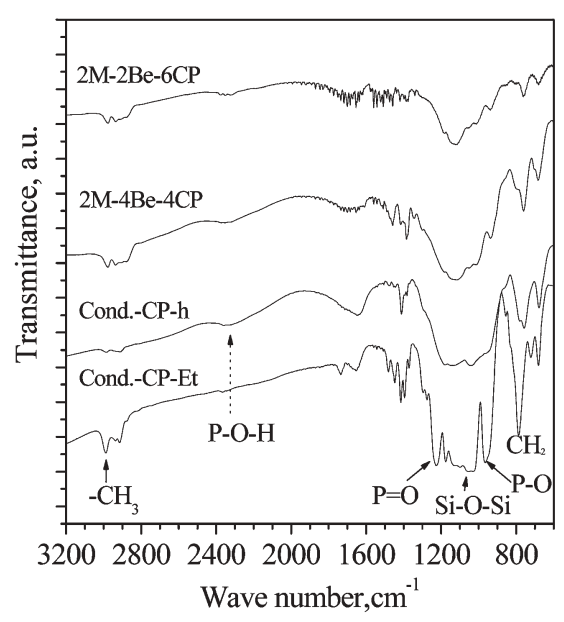

Fig. 1 FTIR spectra of condensed CP-h, condensed CP-Et, and the membranes with compositions of $2 \mathrm{M}-4 \mathrm{Be}-4 \mathrm{CP}$ and $2 \mathrm{M}-2 \mathrm{Be}-6 \mathrm{CP}$. 


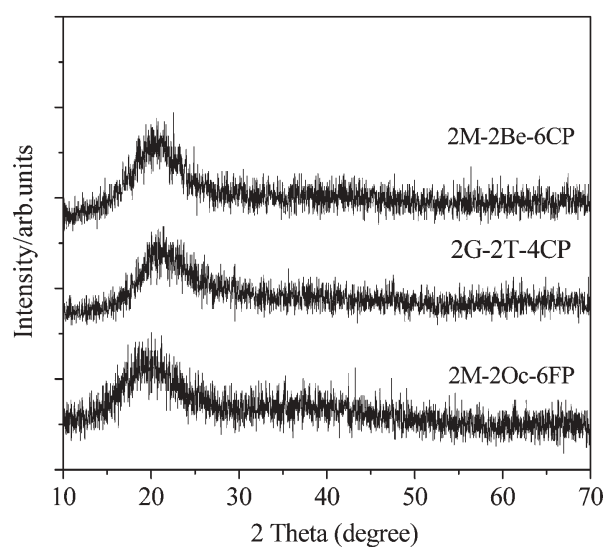

Fig. 2 XRD patterns of the hybrid inorganic-organic polymers with grafted $-\mathrm{PO}_{3} \mathrm{H}_{2}$ groups.

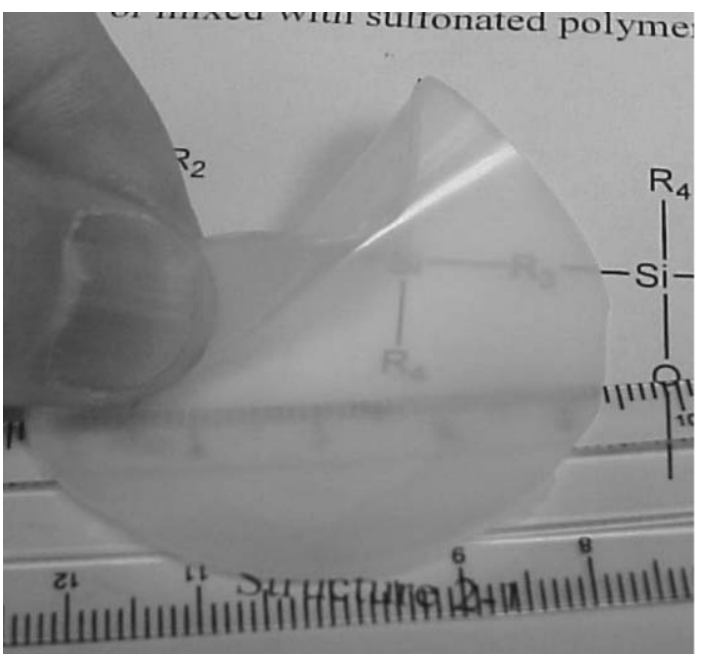

Fig. 3 Appearance of the membrane with a composition of 2M-2T-6CP.

with $-\mathrm{CF}_{2}-\mathrm{PO}_{3} \mathrm{H}_{2}$ groups must be stirred at room temperature for at least 48 hours to form thick sols. If the sols are too thin, the obtained membranes display severe phase separation: a brittle upper layer (mainly composed of the condensed FP-h) and a soft lower layer (mainly composed of the hybrid inorganic-organic copolymers introduced by the precursor M). The shrinkage of the membranes in the drying process decreases with increasing $\mathrm{G}$ or $\mathrm{M}$ content. The volumetric shrinkage rate of $1 \mathrm{Be}-1 \mathrm{CP}$ is about $50 \%$, but there was no observable shrinkage for the membranes with composition of 2M-2Oc (or Be)-6CP and 1G-1CP. The membranes with $\mathrm{G}$ become very soft above $80{ }^{\circ} \mathrm{C}$ in the atmosphere with relative humidity close to $100 \%$ when the content of precursor $\mathrm{G}$ is high (G/CP $>1$ in mol). The membranes with compositions of $x \mathrm{M}-y \mathrm{Oc}$ (or $\mathrm{Be}$ )-zCP (or $\mathrm{FP}$ ) are more flexible when saturated with water than in anhydrous states, but retain adequate mechanical strength at temperatures up to $120{ }^{\circ} \mathrm{C}$ with $\sim 100 \%$ relative humidity.

\subsection{Status of $-\mathrm{PO}_{3} \mathrm{H}_{2}$ groups in the membranes}

${ }^{31} \mathrm{P}$ NMR spectra of the membranes with compositions of $2 \mathrm{M}-4 \mathrm{Be}-4 \mathrm{CP}$ and $2 \mathrm{M}-2 \mathrm{Oc}-6 \mathrm{FP}$ were acquired to further check

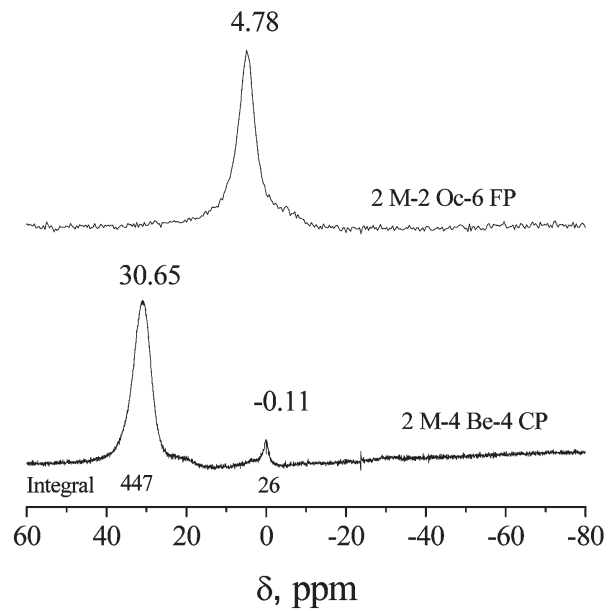

Fig. $4{ }^{31} \mathrm{P}$ NMR spectra of the membranes with compositions of $2 \mathrm{M}-2 \mathrm{Oc}-6 \mathrm{FP}$ and $2 \mathrm{M}-2 \mathrm{Be}-4 \mathrm{CP}$.

the status of the phosphoric acid groups in the membranes (see Fig. 4). In the spectrum of the membrane $2 \mathrm{M}-4 \mathrm{Be}-4 \mathrm{CP}$, two ${ }^{31} \mathrm{P}$ resonance peaks were observed at $\delta=-0.1 \mathrm{ppm}$ and $+30.65 \mathrm{ppm}$, respectively. The extremely strong peak at $\delta=$ $30.65 \mathrm{ppm}$ is attributed to the $-\mathrm{PO}_{3} \mathrm{H}_{2}$ groups grafted on aliphatic chains via $\mathrm{C}-\mathrm{P}$ bonds. ${ }^{24-26}$ To assign the weak peak at $\delta=-0.11 \mathrm{ppm}$, the liquid ${ }^{31} \mathrm{P} \mathrm{NMR}$ spectrum of the starting reagent CP (95\%) was checked, revealing a strong peak at $33.9 \mathrm{ppm}$ and a weak peak at $7.95 \mathrm{ppm}$. The integral of the weak one is $1.2 \%$ of total. This weak peak is from an unknown impurity of the starting agent CP. ${ }^{24}$ Although the integral of the weak peak at $-0.11 \mathrm{ppm}$ in the spectrum of the sample $2 \mathrm{M}-4 \mathrm{Be}-4 \mathrm{CP}$ is about $4.3 \%$ of the total, further investigation may be necessary to confirm the assignment of the weak peak. Only one strong peak at $4.78 \mathrm{ppm}$ was observed in the ${ }^{31} \mathrm{P}$ NMR spectrum of the membrane with grafted $-\mathrm{CF}_{2}-\mathrm{PO}_{3} \mathrm{H}_{2}$ groups. Compared with that of $-\mathrm{CH}_{2}-$ $\mathrm{PO}_{3} \mathrm{H}_{2}$ groups, the ${ }^{31} \mathrm{P}$ NMR peak of $-\mathrm{CF}_{2}-\mathrm{PO}_{3} \mathrm{H}_{2}$ moved much to the negative side, confirming that the $-\mathrm{CF}_{2}-$ group has a strong electron-withdrawing effect on the $-\mathrm{PO}_{3} \mathrm{H}_{2}$ groups. It is noted that all the $-\mathrm{PO}_{3} \mathrm{H}_{2}$ groups in the membranes did not react with $\mathrm{SiO}$ networks in the new hybrid inorganic-organic membranes to form $\mathrm{Si}-\mathrm{O}-\mathrm{P}$ bonds. These acid groups will act as proton donors and acceptors and make a contribution to proton conduction.

\subsection{Thermal and chemical stability of the membranes}

Shown in Fig. 5 are the TGA curves of several samples together with the DSC curve of a sample with composition of $1 \mathrm{G}-1 \mathrm{CP}$ in dry air from room temperature to $500{ }^{\circ} \mathrm{C}$. There are mainly two mass-loss steps in the TGA curves. The small weight loss below the decomposition temperatures corresponds to the evaporation of the small organic molecules and water including that produced by the condensation of $-\mathrm{PO}_{3} \mathrm{H}_{2}$ groups in the membranes. The decomposition of the organic part of the copolymers starts from $220{ }^{\circ} \mathrm{C}, 240{ }^{\circ} \mathrm{C}$, $250{ }^{\circ} \mathrm{C}$ and $280{ }^{\circ} \mathrm{C}$ for the membranes with composition of 2M-2Oc-6CP, 2M-4Be-4CP, 2M-2Oc-6FP, and $1 \mathrm{G}-1 \mathrm{CP}$, respectively. Correspondingly exothermic peaks near the 


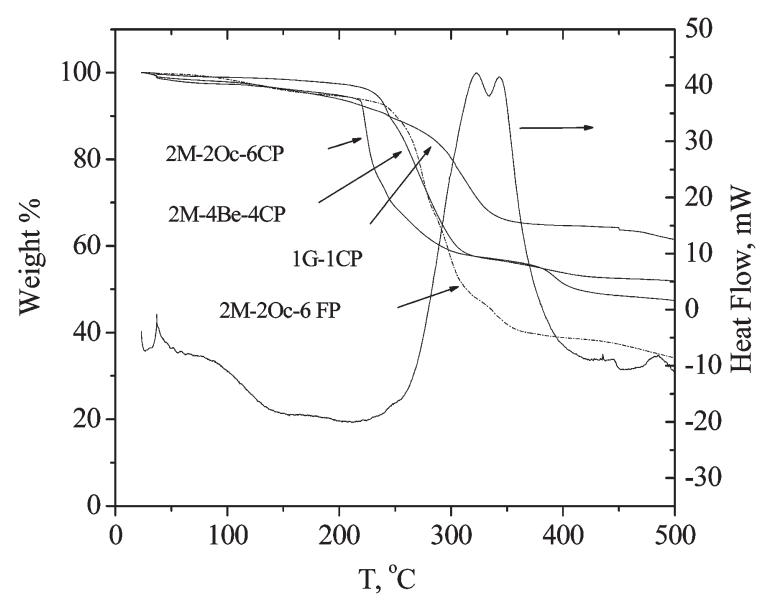

Fig. 5 TGA-DSC curves of the membranes with $-\mathrm{PO}_{3} \mathrm{H}_{2}$ groups as measured in dry air with a heating rate of $5{ }^{\circ} \mathrm{C} \mathrm{min}^{-1}$. The DSC curve is for the membrane with a composition of $1 \mathrm{G}-1 \mathrm{CP}$.

decomposition temperature appear in the DSC curves. The hybrid inorganic-organic membranes are therefore stable up to $220{ }^{\circ} \mathrm{C}$ in dry air.

The chemical stability was examined by immersing a piece of sample $(0.5 \mathrm{~cm} \times 1 \mathrm{~cm})$ in a standard Fenton reagent $(3 \%$ $\mathrm{H}_{2} \mathrm{O}_{2}$ aqueous solution with 2 ppm $\mathrm{FeSO}_{4}$ ) at $80{ }^{\circ} \mathrm{C}$. ${ }^{27}$ It was found that the samples derived from precursor CP, FP and network formers $\mathrm{M}, \mathrm{Be}$ and Oc were stable (no dissolution, no cracking, and no visible changes in mechanical flexibility and strength) after immersion in the solution at $80{ }^{\circ} \mathrm{C}$ for 24 hours. These results suggest that the new membranes have good chemical stability for fuel cell applications.

\subsection{Proton conductivity in anhydrous state}

Shown in Fig. 6 are the proton conductivities measured in dry Ar of the membranes after being dried at $80{ }^{\circ} \mathrm{C}$ for 6 hours and $100{ }^{\circ} \mathrm{C}$ for 2 hours. The proton conductivity of all the membranes increased with temperature, reaching $1.2 \times$ $10^{-4} \mathrm{~S} \mathrm{~cm}^{-1}$ at $120{ }^{\circ} \mathrm{C}$ for the membrane with a composition

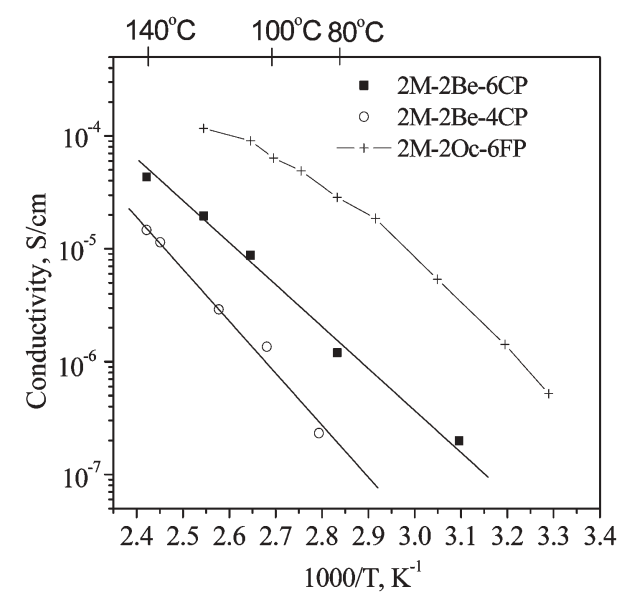

Fig. 6 Proton conductivities of membranes with grafted $-\mathrm{PO}_{3} \mathrm{H}_{2}$ groups as measured in dry argon. of 2M-2Oc-6FP. Comparing the conductivity data of the membranes $2 \mathrm{M}-2 \mathrm{Be}-4 \mathrm{CP}$ and $2 \mathrm{M}-2 \mathrm{Be}-6 \mathrm{CP}$, the proton conductivity increased with $-\mathrm{PO}_{3} \mathrm{H}_{2}$ content, suggesting that the dissociation among the $-\mathrm{PO}_{3} \mathrm{H}_{2}$ groups grafted on the hybrid inorganic-organic copolymer network contributed to proton conduction in the membranes through the Grotthuss mechanism. ${ }^{26,28}$ The sample with grafted $-\mathrm{CF}_{2}-\mathrm{PO}_{3} \mathrm{H}_{2}$ groups had a higher proton conductivity than that with grafted $-\mathrm{CH}_{2}-\mathrm{PO}_{3} \mathrm{H}_{2}$ groups when they had the same $-\mathrm{PO}_{3} \mathrm{H}_{2}$ content. This can be attributed to the fact that $-\mathrm{CF}_{2}-\mathrm{PO}_{3} \mathrm{H}_{2}$ groups have higher acidity because of the large electronwithdrawing effect of $-\mathrm{CF}_{2}-$ groups. The dissociation among $-\mathrm{CF}_{2}-\mathrm{PO}_{3} \mathrm{H}_{2}$ groups can produce more mobile protons for transport than $-\mathrm{CH}_{2}-\mathrm{PO}_{3} \mathrm{H}_{2}$ groups. ${ }^{29}$ The higher proton conductivity of the membrane with grafted $-\mathrm{CF}_{2}-\mathrm{PO}_{3} \mathrm{H}_{2}$ groups may have some relation to its structural characteristics. However, it has to be pointed out that the structural characteristics of the membrane with grafted $-\mathrm{CF}_{2}-\mathrm{PO}_{3} \mathrm{H}_{2}$ groups may contribute to the observed high proton conductivity as well. The chain that connects $-\mathrm{CF}_{2}-\mathrm{PO}_{3} \mathrm{H}_{2}$ with $\mathrm{Si}$ is longer than that connecting $-\mathrm{CH}_{2}-\mathrm{PO}_{3} \mathrm{H}_{2}$ with $\mathrm{Si}$ (see Schemes 1 and 2). Meanwhile, the polymers derived from FP were more flexible than those derived from CP because FP contains diethoxy(methyl)silyl groups, and the backbone of the polymers derived from FP is more linear. The grafted $-\mathrm{CF}_{2}-\mathrm{PO}_{3} \mathrm{H}_{2}$ groups have higher local mobility, and the protons can be transported faster via structure diffusion (Grotthuss mechanism). ${ }^{28}$

\subsection{Water uptake}

The water uptake rate in relative humidity $100 \%$ was calculated by the weight change between the dried (in dry Ar at $70{ }^{\circ} \mathrm{C}$ for about 12 hours) and water-saturated (in closed water chamber for 24 hours at room temperature) samples. As summarized in Table 1, one mole of $-\mathrm{PO}_{3} \mathrm{H}_{2}$ groups in the hybrid inorganic-organic polymer membranes absorb 2.6-5.2 moles of water, depending on the composition of the membrane. Compared with polymers such as poly(vinyl acrylate phosphoric acid) and phosphonic acid functionalized poly(aryloxyphosphazene), in which one mole of acid groups can usually absorb at least 12 moles of water, ${ }^{12,30,31}$ the new hybrid inorganic-organic membranes with $-\mathrm{PO}_{3} \mathrm{H}_{2}$ groups absorbed much less water. It was reported that the water uptake of polymer materials with grafted acid groups is controlled by the molecular structures of the materials. ${ }^{12}$ For

Table 1 Proton conductivity and water uptake of the membranes

\begin{tabular}{|c|c|c|c|c|c|}
\hline \multirow[b]{2}{*}{ Composition } & \multicolumn{2}{|c|}{ Conductivity/S cm ${ }^{-1}$} & \multicolumn{2}{|c|}{ Water uptake } & \multirow[b]{2}{*}{$E_{\mathrm{a}} / \mathrm{eV}$} \\
\hline & $25^{\circ} \mathrm{C}$ & $100{ }^{\circ} \mathrm{C}$ & Weight $\%$ & {$\left[\mathrm{H}_{2} \mathrm{O} /-\mathrm{PO}_{3} \mathrm{H}_{2}\right]$} & \\
\hline $2 \mathrm{M}-4 \mathrm{Be}-4 \mathrm{CP}$ & - & $5.8 \times 10^{-3}$ & 10.8 & 2.6 & 0.70 \\
\hline $2 \mathrm{M}-2 \mathrm{Be}-4 \mathrm{CP}$ & $1.0 \times 10^{-3}$ & $8.5 \times 10^{-3}$ & 15.0 & 3.1 & 0.26 \\
\hline $2 \mathrm{M}-2 \mathrm{Be}-6 \mathrm{CP}$ & $1.3 \times 10^{-3}$ & $2.2 \times 10^{-2}$ & 26.5 & 4.4 & 0.27 \\
\hline $2 \mathrm{M}-2 \mathrm{Oc}-6 \mathrm{CP}$ & $1.5 \times 10^{-3}$ & $6.2 \times 10^{-2}$ & 23.6 & 5.1 & 0.32 \\
\hline 2M-2Oc-6FP & - & $1.1 \times 10^{-2}$ & 13.6 & 5.4 & $\begin{array}{l}0.05 / \\
1.5^{a}\end{array}$ \\
\hline $\begin{array}{l}\text { 4Oc-6FP } \\
{ }^{a} E_{\mathrm{a}} \text { value be }\end{array}$ & $\begin{array}{l}2.2 \times 10^{-3} \\
\text { low } 70^{\circ} \mathrm{C} \text {. }\end{array}$ & $5.0 \times 10^{-2}$ & 25.2 & 5.2 & 0.30 \\
\hline
\end{tabular}


example, in S-PPBP (sulfonated poly(4-phenoxybenzoyl-1,4phenylene)) and S-PEEK (sulfonated poly(oxy-1,4-phenyleneoxy-1,4-phenylenecarbonyl-1,4-phenylene)), one mole of $-\mathrm{SO}_{3} \mathrm{H}$ can absorb 9 and 3 moles of water, respectively, in relative humidity $100 \%$ at room temperature owing to the flexible side chains of S-PPBP.,12 The lower water uptake of the new hybrid inorganic-organic copolymer membranes may be attributed to the tight inorganic - $\mathrm{Si}-\mathrm{O}-\mathrm{Si}-\mathrm{O}-$ networks.

\subsection{Humidity dependence of proton conductivity}

Shown in Fig. 7 is the humidity dependence of the proton conductivity of the membrane with a composition of $2 \mathrm{M}-2 \mathrm{Oc}-$ $6 \mathrm{CP}$ at $80{ }^{\circ} \mathrm{C}$ and $100{ }^{\circ} \mathrm{C}$. The proton conductivity at $80{ }^{\circ} \mathrm{C}$ increases from $10^{-6} \mathrm{~S} \mathrm{~cm}^{-1}$ in dry argon to $2.3 \times 10^{-3} \mathrm{~S} \mathrm{~cm}^{-1}$ at $\sim 20 \% \mathrm{RH}$ and $1.76 \times 10^{-2} \mathrm{~S} \mathrm{~cm}^{-1}$ at $\sim 100 \% \mathrm{RH}$. The dramatic increase in the proton conductivity of these membranes in wet atmosphere can be attributed to the fast transport of $\mathrm{H}_{3} \mathrm{O}^{+}$in a vehicle mechanism. ${ }^{28,29}$ Comparing the proton conductivity dependence on $\mathrm{RH}$ of the new hybrid inorganic-organic membranes with that of most sulfonatedaromatic polymers, ${ }^{12}$ one can find that the new membranes with grafted $-\mathrm{PO}_{3} \mathrm{H}_{2}$ groups display much higher proton conductivity in low RH. For example, the proton conductivity of sulfonated poly(oxy-1,4-phenyleneoxy-1,4-phenylenecarbonyl-1,4-phenylene) (S-PEEK, 65\% sulfonation) is less than $10^{-6} \mathrm{~S} / \mathrm{cm}^{-1}$ at $\mathrm{RH}<50 \%{ }^{12}$ The new membrane with a composition of $2 \mathrm{M}-2 \mathrm{Oc}-6 \mathrm{CP}$ had a proton conductivity similar to Nafion ${ }^{\circledR} 117$ at $80{ }^{\circ} \mathrm{C}$ and $100{ }^{\circ} \mathrm{C}$ at both low $\mathrm{RH}$ and high RH (see Fig. 7).

The proton conductivities of all obtained membranes were measured at $\sim 100 \% \mathrm{RH}$ from room temperature to $100{ }^{\circ} \mathrm{C}$. The membranes with precursor $\mathrm{G}$ had a proton conductivity of $10^{-3} \mathrm{~S} \mathrm{~cm}^{-1}$ below $80{ }^{\circ} \mathrm{C}$. Shown in Fig. 8 is the temperature dependence of proton conductivities of the precursor M-based membranes. The proton conductivity increased with $-\mathrm{PO}_{3} \mathrm{H}_{2}$ content, and reached $10^{-2} \mathrm{~S} \mathrm{~cm}^{-1}$ at $100{ }^{\circ} \mathrm{C}$ when the molar ratio of $-\mathrm{PO}_{3} \mathrm{H}_{2} / \mathrm{Si}$ was larger than 0.5 in the membranes. It was $6.2 \times 10^{-2} \mathrm{~S} \mathrm{~cm}^{-1}$ for the sample with a composition of

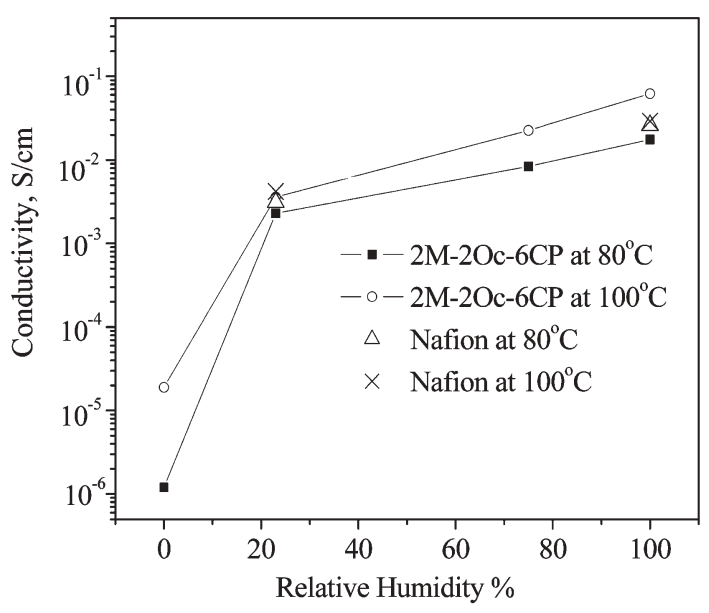

Fig. 7 Humidity dependence of the proton conductivity of a membrane with composition of $2 \mathrm{M}-2 \mathrm{Oc}-6 \mathrm{CP}$ at $80{ }^{\circ} \mathrm{C}$ and $100{ }^{\circ} \mathrm{C}$, compared with those of Nafion 117.

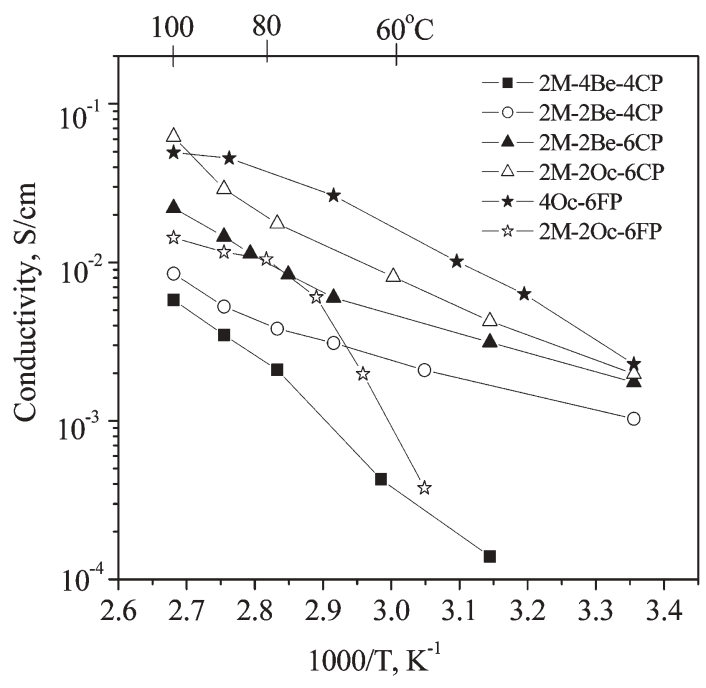

Fig. 8 Proton conductivity measured at $100 \%$ relative humidity of membranes with compositions of $x \mathrm{M}-y \mathrm{Be}-z \mathrm{CP}(x=2, y=2$ and $4, z=4$ and 6), 2M-2Oc-6CP, 2M-2Oc-6FP, and 4Oc-6FP.

$2 \mathrm{M}-2 \mathrm{Oc}-6 \mathrm{CP}$ at $100{ }^{\circ} \mathrm{C}$. The proton conductivity of the new hybrid inorganic-organic membranes is comparable with that of Nafion ${ }^{\circledR}$ and sulfonated aromatic polymer membranes, ${ }^{12,30,32}$ and much higher than other polymer membranes with $-\mathrm{PO}_{3} \mathrm{H}_{2}$ groups, for example, phosphoxyethyl-trifloroethylacrylate (PHM-TFEA) copolymer membranes (about $5 \times$ $10^{-3} \mathrm{~S} \mathrm{~cm}^{-1}$ at $100{ }^{\circ} \mathrm{C}$ and $\left.100 \% \mathrm{RH}\right) .{ }^{12,30}$ The high proton conductivity of the new hybrid inorganic-organic copolymer membranes was achieved with a smaller amount of water compared with other polymer membranes. The water uptake in polymer membranes includes two parts: one is for solvation of the protons and acid groups, the other for polymer swelling. ${ }^{12}$ The water uptake of the hybrid inorganic-organic copolymer membrane grafted $-\mathrm{PO}_{3} \mathrm{H}_{2}$ groups is enough for the solvation of acid groups and for fast transport of $\mathrm{H}_{3} \mathrm{O}^{+}$ ions. This may be related to the specific hybrid inorganicorganic network in the new membranes based on a tight - $\mathrm{Si}-\mathrm{O}-\mathrm{Si}-\mathrm{O}$ - inorganic backbone and highly flexible organic chains formed by PPO because these networks as good proton acceptors may assist proton transport. ${ }^{33}$

It is noted that the membranes derived from precursor Oc has higher proton conductivity than those derived from precursor $\mathrm{Be}$ when they have the same content of $-\mathrm{PO}_{3} \mathrm{H}_{2}$ groups. The main reason may be that $-\mathrm{PO}_{3} \mathrm{H}_{2}$ groups in the membrane with Oc can absorb a little more $\mathrm{H}_{2} \mathrm{O}$ than those in the membrane with Be. Another reason is that the aliphatic chains introduced by Oc are more flexible than the aromatic ring containing chains introduced by Be. The membrane with flexible Oc chains may have larger domains in which water can form pathways for proton transport. ${ }^{12,34}$ However, it is still difficult to explain the behavior of the membranes derived from FP; the membrane with composition of $2 \mathrm{M}-2 \mathrm{Oc}-6 \mathrm{FP}$ has lower proton conductivity than $2 \mathrm{M}-2 \mathrm{Oc}-6 \mathrm{CP}$ and $2 \mathrm{M}-2 \mathrm{Be}-$ $6 \mathrm{CP}$ although it has a more flexible network owing to its linear structure derived from the methyldihydroxysilyl groups in precursor FP-h (see Scheme 1). In contrast, the sample with higher content of cross-linker, 4Oc-6FP, has much higher 
proton conductivity than 2M-2Oc-6FP (see Fig. 8). These results indicate that the higher acidity of $-\mathrm{CF}_{2}-\mathrm{PO}_{3} \mathrm{H}_{2}$ groups may have little effect on the proton conductivity of the membranes in a high $\mathrm{RH}$ environment, but the morphologies and the molecular structures of the membranes are more important to the proton transport process.

Shown in Fig. 8 are the proton conductivities of all samples measured from room temperature to $100{ }^{\circ} \mathrm{C}$. The $\log \sigma \sim 1 / T$ curves of the samples, especially those derived from precursor $\mathrm{CP}-\mathrm{h}$, are nearly linear, indicating that the proton conductivity of these samples exhibits Arrhenius-type behavior. The activation energy was estimated from the slopes of the Arrhenius plots (Fig. 8). The average activation energy for the temperature range studied tends to decrease with increasing the content of the $-\mathrm{PO}_{3} \mathrm{H}_{2}$ group (see Table 1). The estimated average activation energy is $0.71 \mathrm{eV}\left(68.5 \mathrm{KJ} \mathrm{mol}^{-1}\right)$ for the membrane $2 \mathrm{M}-4 \mathrm{Be}-4 \mathrm{CP}\left(-\mathrm{PO}_{3} \mathrm{H}_{2} / \mathrm{Si}=4 / 10\right.$ in $\left.\mathrm{mol}\right)$ and about $0.3 \mathrm{e} \mathrm{V}\left(28.9 \mathrm{KJ} \mathrm{mol}^{-1}\right)$ for the other four membranes with higher contents of $-\mathrm{PO}_{3} \mathrm{H}_{2}$ groups. The latter value is comparable to that of Nafion ${ }^{\mathbb{B}}$ membranes, indicating that the new membranes may have a similar conduction mechanism involving the hydronium ions. ${ }^{35}$ There is an obvious change of slope coefficient in the $\log \sigma \sim 1 / T$ curve of the sample with composition 2M-2Oc-6FP, indicating an activation energy change near $70{ }^{\circ} \mathrm{C}$. Comparing the $\log \sigma \sim 1 / T$ curve of this sample in humidified environment with that in the anhydrous state, one can find that this activation energy change may be related with the changes in morphologies of this membrane with temperature under fully humidified conditions.

\section{Conclusion}

The new membranes with $-\mathrm{PO}_{3} \mathrm{H}_{2}$ groups grafted on the hybrid inorganic-organic networks formed among the alkoxysilanes $\mathrm{M}, \mathrm{Be}, \mathrm{Oc}, \mathrm{T}$, and $\mathrm{G}$ have good stability and high proton conductivity $\left(>10^{-2} \mathrm{~S} \mathrm{~cm}^{-1}\right.$ above $\left.50{ }^{\circ} \mathrm{C}\right)$ under humidified conditions. Compared with the organic polymer membranes containing acid groups, the hybrid inorganicorganic copolymer membranes can achieve high proton conductivity with much less water and thus have much less dependence on humidity. They have great potential for application in PEM fuel cells and other electrochemical devices, especially for high temperature and low relative humidity. The physical state of water and the proton transport mechanism in these hybrid inorganic-organic membranes are yet to be determined, which would be essential to intelligent design of new membranes with high proton conductivity and adequate stability for practical applications.

\section{List of Abbreviations}

Oc: bis(triethoxysilyl)octane; Be: bis(trimethoxysilylethyl)benzene; CP: diethoxyphosphorylethyltriethoxysilane; CP-Et: diethoxyphosphorylethyltrihydroxysilane; FP: diethyl4-(diethoxy(methyl)silyl)-1,1-difluorobutylphosphonate; G: (3-glycidoxypropyl)triethoxysilane; FP-h: 4-(dihydroxy(methyl)silyl)-1,1-difluorobutylphosphonate; M: bis[(3-methyldimethyoxysilyl)propyl]polypropylene oxide; CP-h: dihydroxyphosphorylethyltrihydroxysilane; T: tetraethoxysilane.

\section{References}

1 L. Depre, M. Ingram, C. Poinsignon and M. Popall, Electrochim. Acta, 2000, 45, 1377-83.

2 K. D. Kreuer, J. Memb. Sci., 2001, 185, 29-39.

3 J. M. Bae, I. Honma, M. Murata, T. Yamamoto, M. Rikukawa and N. Ogata, Solid State Ionics, 2002, 147, 189-94.

4 N. Chen and L. Hong, Solid State Ioncs, 2002, 146, 377-85.

5 S. Surampudi, S. R. Narayanan, E. Vamos, H. Frank, G. Halpert, A. LaConti, J. Kosek, G. K. Surya Prakash and G. A. Olah, J. Power Source, 1994, 47, 377-85.

6 A. J. Appleby and F. R. Foulkes, ed., Fuel Cell Handbook, Malabar, FL: Krieger, 1993.

7 K. Tsuruhara, M. Rikukawa, K. Sanui, N. Ogata, Y. Nagasaki and M. Kato, Electrochim. Acta, 2000, 45, 1391-4.

8 M. Watanabe, H. Uchida and M. Emori, J. Phys. Chem. B, 1998, 102, 3129-37

9 H. Wang, B. A. Holmberg, L. Huang, Z. Wang, A. Mitra, J. M. Norbeck and Y. Yan, J. Mater. Chem., 2002, 12, 834-7.

10 J. S. Wainright, J.-T. Wang, D. Weng, R. F. Savinell and M. Lit, $J$ Electrochem Soc., 1995, 142, L121.

11 A. Schechter and R. Savinell, Solid State Ionics, 2002, 147, 181-7.

12 M. Rikukawa and K. Sanui, Prog. Polym. Sci., 2000, 25, 1463-502.

13 A. Matsuda, T. Kanzaki, Y. Yoshinori, M. Tatsuminago and T. Minami, Solid State Ionics, 2001, 139, 113-9.

14 K. Hirata, A. Matsuda, T. Hirata, M. Tatsumisago and T. Minami, J. Sol-gel Sci. Tech., 2000, 17, 61-9.

15 A. Matsuda, T. Kanzaki, M. Tatsuminago and T. Minami, Solid State Ionics, 2001, 145, 161-6.

16 M. Popall and X. M. Du, Electrochim. Acta, 1995, 40, 2305-8.

17 W. Qiu and D. J. Burton, Tetrahedron Lett., 1996, 37, 2745-8.

18 D. J. Burton and L. G. Sprague, J. Org. Chem., 1989, 54, 613-7.

19 Th. Dippel, K. D. Kreuer, J. C. Lassegues and D. Rodriguez, Solid State Ionics, 1993, 61, 41-6.

20 N. B. Colthup, L. H. Daly and S. E. Wiberley, Introduction to Infrared and Raman Spectroscopy, Academic Press, New York, 1964, p.403.

21 N. B. Colthup, L. H. Daly and S. E. Wiberley, Introduction to Infrared and Raman Spectroscopy, Academic Press, New York, 1964, p.324.

22 Y. Park and M. Nagai, Solid State Ionics, 2001, 145, 149-60.

23 L. D. Carlos, V. de Zea Bermudez, R. A. Ferrerira, L. Marques and M. Assuncao, Chem. Mater., 1999, 11, 581-8.

24 P. Kohli and G. J. Blanchard, Langmuir, 2000, 16, 695.

25 A. Aliev, D. Ou, B. Ormsby and A. C. Sullivan, J. Mater. Chem., 2000, 10, 275-81.

26 S. Li and M. Liu, Electrochim. Acta, 2003, 48, 4271-5.

27 K. Miyatake, N. Asano and M. Watanabe, J. Polym. Sci.: A, 2003, 41, 3901-.

28 K. D. Kreuer, Chem. Mater., 1996, 8, 610-41.

29 D. R. Lide, CRC Handbook of Chemistry and Physics, CRC Press, Boca Raton, Fla.0, 1998, p15-26.

30 K. Kaneko, Y. Takeoka, M. Aizawa and M. Rikukawa, Synth. Met., 2003, 135-136, 73-4.

31 H. R. Allcock, M. A. Hofmann, C. M. Ambler, S. N. Lvov, X. Y. Zhou, E. Chalkova and J. Weston, J. Memb. Sci., 2002, 201, $47-54$.

32 K. Miyatake, H. Iyotani, K. Yamamoto and E. Tsuchida, Macromole., 1996, 29, 6969-71.

33 J. Qiao, N. Yoshimoto and M. Morita, J. Power Sources, 2002, 105, 45-51.

34 M. A. Hickner and B. S. Pivovar, Fuel Cells, 2005, 5, 213-29.

35 P. C. Rieke and N. E. Vanderborgh, J. Memb. Sci., 1987, 32, 313-28. 